\title{
Oestrogen's masculine side: mediation of mating in male mice
}

\author{
Elka M. Scordalakes, Dennis B. Imwalle and Emilie F. Rissman* \\ Department of Biology, University of Virginia, Charlottesville, VA 22903, USA
}

\begin{abstract}
This review focuses on the role of oestrogen in male sexual behaviour using oestrogen receptor $\alpha$ and $\beta$ knockout (ER $\alpha K O$ and $E R \beta K O$ ) mouse models. ER $\beta K O$ mice are capable of mating and producing offspring, whereas ER $\alpha$ KO mice are unable to do either. When ER $\alpha$ KO males are treated with testosterone or dihydrotestosterone (DHT), $<50 \%$ display mounting behaviour, few intromit and none ejaculate. However, concurrent treatment with testosterone and a dopamine agonist instates masculine sexual behaviour in both male and female ER $\alpha$ KO mice. Dopamine content in the preoptic area and associated regions is not affected by oestrogen receptor $\alpha$ gene disruption. However, expression of neuronal nitric oxide synthase immunoreactivity is severely reduced in ER $\alpha K O$ males compared with wild-type males. These findings, together with studies conducted in aromatase knockout mice, are at odds with the dogma that oestrogen is required during development for expression of male sexual behaviour in adults. However, they do support a role for oestrogens, mediated by oestrogen receptor $\alpha$, in regulation and production of neuronal nitric oxide synthase, which in turn may control dopamine agonist release. As has been shown in male rats, in mice dopamine agonist release is likely to be an essential component of the neural pathway that mediates male sexual behaviour.
\end{abstract}

The presence or absence of the $\mathrm{Y}$ chromosome determines gonadal sex in mammals. If the $Y$ chromosome is present, a genetic cascade that includes activation of the Sry gene (sex determining region of the $Y$ chromosome) causes the undifferentiated gonad to become a testis. In mice, the fetal gonad is determined on day 14.5 of gestation (Lovell-Badge, 1993) and the testes begin to secrete testosterone during the final few days of gestation (Gondos, 1980). This increase in testosterone is responsible for phenotypic sexual differentiation of the external genitalia in most mammals. For example, removal of undifferentiated gonads in genetically male rabbit embryos results in the production of female offspring (Jost, 1970; Wilson, 1989). In contrast, replacement of the indifferent gonad with a testis, irrespective of whether the embryo was genetically male or female, resulted in offspring with male external genitalia and internal ducts (Jost, 1970).

The paradigm of gonadectomy and sex steroid replacement at critical points of development has been used to determine whether reproductive behaviour develops in the same way. Phoenix et al. (1959) injected testosterone into pregnant guinea-pigs. When the female offspring of these guinea-pigs reached adulthood, they were gonadectomized, treated with testosterone and tested for their ability

\footnotetext{
*Address for correspondence: University of Virginia School of Medicine, Department of Biochemistry and Molecular Genetics, 1300 Jefferson Park Avenue, Box 800733, Charlottesville, VA 22908-800733, USA

Email: rissman@virginia.edu
}

to display masculine copulatory behaviour. Females given testosterone injections prenatally and in adulthood displayed more male sexual behaviour than did females that were given vehicle prenatally and testosterone in adulthood (Phoenix et al., 1959). This paradigm was extended by Beach et al. (1969), who castrated rat pups on the day of birth and replaced testosterone on selected days during the first 14 days of life. Male rats given testosterone replacement during the first 4 days after birth were able to display masculine behaviour after testosterone treatment as adults. In contrast, male rats given testosterone after the critical period failed to show male sexual behaviour after priming with testosterone as adults. These and other experiments led to the hypothesis that testosterone has both organizing and activating effects on sexual behaviour in males (Beach et al., 1969; Arnold, 1996). Furthermore, these results show that the organization of neural substrates critical for expression of sexual behaviour is dependent on critically timed exposure to sex steroids.

Subsequent behavioural studies in rodents demonstrated that either testosterone or oestradiol administration to neonatal females resulted in masculinized adult behaviour (Meisel and Sachs, 1994). Likewise, castrated male pups treated with oestradiol display relatively normal adult male sexual behaviour (Meisel and Sachs, 1994), indicating that either testosterone or oestradiol administration at a critical point of development can drive differentiation of sexual behaviour. Naftolin (1994) demonstrated that testosterone is aromatized to oestradiol during fetal development and, thus, may be involved in sexual differentiation of the brain 
(Reddy et al., 1974). In addition, use of drugs that inhibit aromatase yields results that are consistent with the hypothesis that during normal male development testosterone is aromatized to oestradiol and that its actions influence adult behaviour (Houtsmuller et al., 1994).

Both neonatal males and females have aromatase in the preoptic area (POA). Concentrations of aromatase reach a peak just after birth, coincident with the critical period in development for behavioural changes in adults (Lephart et al., 1992). Moreover, males have much higher aromatase activity, mRNA and immunoreactivity than do females, indicating that this process may be more efficient in males (Roselli et al., 1987, 1997; Veney et al., 2000). Overall, aromatase is in the correct place, at the correct time, in the male brain to produce oestradiol.

The effects of oestrogen are transduced via oestrogen receptors. Initial investigations of the mechanisms by which these effects are transduced have used neonatal treatment with oestrogen receptor antagonists (Vega Matuszczyk and Larsson, 1995) or the reduction of available oestrogen receptor protein via neonatal treatment with antisense mRNA (McCarthy et al., 1993). In both of these studies, testosterone propionate (TP) injections were given to masculinize the animals; however, females given an oestrogen receptor antagonist or antisense mRNA at birth showed normal female sexual behaviour, whereas females that did not receive the antagonist or the antisense mRNA were masculinized. These data demonstrate the requirement for functional oestrogen receptors and indicate that androgens must be aromatized to have masculinizing effects on behaviour.

\section{Activational effects of oestrogen on male sexual behaviour}

In addition to organization of the masculine brain and phenotype, androgens may be aromatized to oestradiol to activate adult sexual behaviour. Many studies in rats, hamsters and other mammals have shown that oestradiol can partially, but not completely, reinstate sexual activity in castrated males (Meisel and Sachs, 1994). One interpretation of these data is that aspects of male sexual behaviour are dependent on central actions of androgens acting via an oestrogen receptor, whereas peripheral actions of androgens (that is, tactile and penile stimulation) involve activation of androgen receptors (Baum and Vreeburg, 1973; Meisel and Sachs, 1994). Evidence supporting this hypothesis comes from studies that use non-aromatizable androgens (for example, dihydrotestosterone; DHT) in combination with oestradiol. In these experiments, the combination of oestradiol and DHT was always more effective at reinstating masculine sexual behaviour than administration of oestradiol alone (Baum and Vreeburg, 1973; Davis and Barfield, 1979).

The distribution of androgen receptors and oestrogen receptors in the hypothalamus, POA and limbic regions reveals that both steroid receptors are present, and that they are often co-expressed in the same neurones (Wood and Swann, 2000). In a series of elegant studies in castrated male rats, Vagell and McGinnis (1998) found that central administration of an androgen receptor antagonist could inhibit the restoration of male copulatory behaviour after castration and testosterone replacement. Concurrent treatment with testosterone and an aromatase inhibitor failed to reinstate sexual behaviour, indicating that oestrogen receptors and androgen receptors are both necessary for normal male sexual behaviour (Vagell and McGinnis, 1997). Additional evidence for a requirement for androgen receptors comes from spontaneous mutants resulting from a single base deletion in the androgen receptor gene (Gaspar et al., 1991). This condition, referred to as testicular feminization $(T f m)$, creates genetic $(X Y)$ males that appear externally female and have reduced masculine sexual behaviour (Olsen, 1992).

\section{Effects of oestrogens on male sexual motivation}

A male must be sexually motivated for masculine sexual behaviour to be initiated. Motivation requires that males be capable of recognizing a female as a potential sexual partner and that they seek mating opportunities with a female. Moreover, males must find interactions with females rewarding for the behaviour to persist. Many paradigms have been used to assess sexual motivation in male mammals. For example, males have been forced to traverse an electrified grid (Prince et al., 1998), trained to bar press at a particular rate (Meisel and Sachs, 1994) or placed on a treadmill and forced to run for an interaction with a female (Craigen and Bronson, 1982). The most commonly used task is simply to give the male a choice of male and female animals and to determine how much time it takes the male to contact each animal and which one he spends most of his time with (Merkx, 1984). Generally, males choose to spend more time with females than other males. Castration removes, whereas testosterone replacement restores, preference for females in oestrus or females treated with oestradiol (Merkx, 1984). Normal female rats have a preference for males, but neonatal administration of testosterone or oestradiol switches their preference to females. Finally, males exposed to anti-oestrogens or aromatase inhibitors during the neonatal period have feminized preferences as adults (Bakker et al., 1996).

\section{Oestrogen and masculine sexual behaviour in mice}

The mouse has emerged as an excellent tool for work in behavioural neuroendocrinology because the mouse genome was the first rodent genome to be sequenced and also because it is technically straightforward to manipulate mouse embryonic stem cells, and to inject mouse blastocytes with transgenes to generate specific knockout mice. An under-appreciated advantage of mice is the presence of strain differences in behaviour that were first documented in the 1960s and 1970s (McGill, 1962; Vale et al., 1973; 
Holman, 1976). This diversity in behaviour among inbred strains (Crawley et al., 1997), combined with the power of genetics, will lead to new discoveries about genetic regulation of sexual behaviour.

In male CD-1, Swiss-Webster and C57BL/6J mice, oestradiol, testosterone or other aromatizable androgens can reinstate male copulation after castration (Luttge and Hall, 1973; Nyby et al., 1977; Nunez et al., 1978; Bean et al., 1986). In CD-1 males, DHT was also able to elicit good masculine behaviour (Luttge and Hall, 1973). In addition, female mice of Swiss-Webster, C57BL/6J and C57BL/6Fa strains can show male-like copulatory behaviour, including mounting with pelvic thrusts, when they are ovariectomized and treated with testosterone in adulthood (Edwards and Burge, 1971; Vale et al., 1973; Holman, 1976; Wersinger and Rissman, 2000a). This effect was not noted in DBA/2 females, but F1 females from DAB/2 and C57BL/6Fa parents were able to display masculine behaviour regardless of the strain of origin for the sire versus the dam (Holman, 1976).

This finding in female hybrids can be compared with data from hybrid male mice bred from C57BL/6 dams and $\mathrm{DBA} / 2$ sires, which continue to copulate after castration, whereas males from the reciprocal cross do not (McGill, 1962). To our knowledge, the ability of female mice to retain expression of masculine behaviour after testosterone depletion has not been tested. Measures of aromatase activity, plasma oestradiol concentrations and numbers of oestrogen receptors or androgen receptors in the brain cannot account for this behavioural difference (Clemens et al., 1988). Genetic imprinting or a gene present on the maternal $X$ or paternal $Y$ chromosome may be involved in this behavioural insensitivity to castration. Given that the androgen receptor gene is on the $X$ chromosome, one possibility may be that a sex-linked mutation results in ligand-independent androgen receptor gene activation in the C57BL/6 strain. Finally, work with two different aromatase knockout mice strains shows that males can sire litters when they are young, but lose this capacity as they age and perform some, albeit reduced, masculine sexual behaviour when tested in adulthood (Honda et al., 1998; Robertson et al., 2001). As these mice are unable to convert testosterone to oestradiol, the data indicate strongly that neonatal oestradiol may not be essential for adult expression of masculine sexual behaviour, at least in genetic males.

Although these strain differences in steroidal actions on sexual behaviour are confusing, they can be used to increase our knowledge of hormone and gene interactions. Overall, testosterone and its metabolites are implicated in the display of masculine sexual behaviour. Moreover, depending on the mouse strain selected, little sexual dimorphism in this behaviour may be present. Taken with the data reviewed for rats earlier, we predict that in some mouse strains (for example, C57BL/6J) either oestradiol plays little role in organization of masculine behaviour in mice, or both males and females are exposed to enough testosterone in utero to masculinize the neural substrates required for masculine sex behaviour. Data from aromatase knockout mice (Honda et al., 1998; Robertson et al., 2001) tend to support the former hypothesis.

\section{ER $\alpha$ KO mice and male sexual behaviour}

In 1996, our laboratory received the oestrogen receptor $\alpha$ knockout mice (ER $\alpha \mathrm{KO}$ ) engineered by Lubahn et al. (1993). Both male and female ER $\alpha$ KO mice are infertile. Sexual behaviour is eliminated in female ER $\alpha$ KO mice (Rissman et al., 1997a) and greatly impaired in males (Wersinger and Rissman, 2000a). A few years after the development of ER $\alpha \mathrm{KO}$ mice, a new oestrogen receptor (oestrogen receptor $\beta$ ) was discovered in ovarian and prostate tissue (Kuiper et al., 1996). An ERßKO mouse was produced using the same techniques used to knockout oestrogen receptor $\alpha$ (Krege et al., 1998). Female ERßKO mice are subfertile, few of them have litters and those that do have fewer pups than their wild-type counterparts (Krege et al., 1998). However, sex behaviour deficiencies in female and male ERßKOs have not yet been described (Ogawa et al., 1999).

Given the reproductive phenotype of the ER $\alpha$ KO mice, we predicted that the action of oestradiol on male sexual behaviour in mice was due to oestrogen receptor $\alpha$ activation. To date, our data support this prediction. After castration and testosterone replacement, up to $50 \%$ of ER $\alpha \mathrm{KO}$ males display some mounting behaviour, yet very few ever intromit and none ejaculate (Rissman et al., 1999; Wersinger and Rissman, 2000a). Furthermore, the male ER $\alpha$ KO mice that do mount have longer latencies than do wild-type males, and the number of times that they show the behaviour is significantly reduced (Wersinger et al., 1997). These differences in copulatory behaviour could be due to deficits in sexual performance or motivation. As described previously, sexual motivation requires that males seek out females as well as attempt to mate with them, but sexual performance is the ability to physically copulate with females once a receptive female is located. Our data indicate that sexual performance may be reduced in male ER $\alpha$ KO mice, at least in part due to a motivational deficit. Although we cannot eliminate the possibility that oestrogen receptor $\alpha$ is also needed for motor aspects of copulation, without motivation, copulatory performance is difficult to assess.

We have tested social preferences in $\mathrm{ER} \alpha \mathrm{KO}$ mice to examine sexual motivation. Normal male rodents that have circulating testosterone preferentially interact with females versus males (Merkx, 1984). We hypothesized that oestradiol, aromatized from testosterone, drives this behaviour, and that the ER $\alpha \mathrm{KO}$ mice would show impaired preference. Male preference was tested in three-chambered choice boxes with a stimulus animal in each end section and a neutral central section. When awake, tethered stimulus mice were used, it was found that castrated testosteronetreated wild-type males spent significantly more time with hormone-primed, female stimulus animals and less time in 


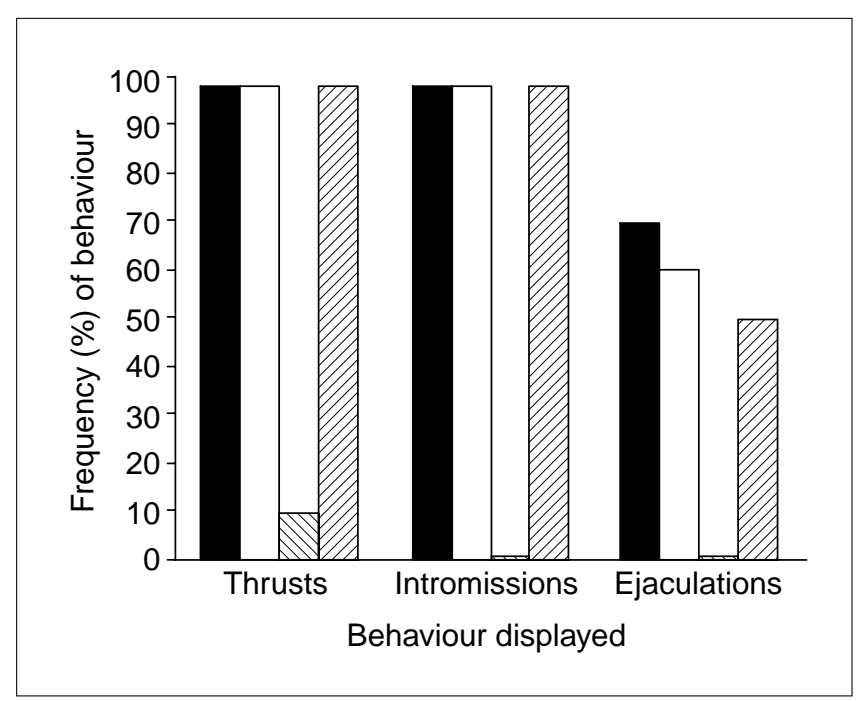

Fig. 1. Percentage of castrated and testosterone-implanted wildtype and oestrogen receptor $\alpha$ knockout (ER $\alpha K O)$ males treated with either vehicle or apomorphine (APO) displaying thrusts, intromissions and ejaculations in a series of sex behaviour tests. Wild-type mice treated with vehicle; $\square$ : wild-type mice treated

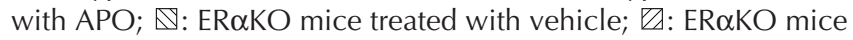
treated with APO. ER $\alpha \mathrm{KO}$ males treated with vehicle showed less behaviour of all types, whereas ER $\alpha$ KO mice treated with APO showed instatement of masculine behaviour comparable to wildtype males. Figure adapted from Wersinger and Rissman (2000a).

the neutral section of the box compared with ER $\alpha$ KO males (Rissman et al., 1997b). When ovariectomized females with or without hormone treatment were used as stimulus animals, it was found that wild-type males spent most time with hormone-treated females and significantly less time with untreated females or alone. The ER $\alpha$ KO males spent more time with females than alone, but they spent equivalent amounts of time with ovariectomized and hormone-

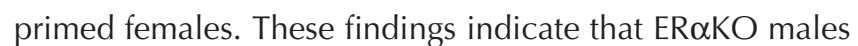
lack a preference for receptive over non-receptive females.

The same type of test was conducted with anaesthetized stimulus mice to eliminate the potential confounding factor that the behavioural interaction with the stimulus animal may influence the male's behaviour. Thus, if ER $\alpha$ KO males were attracted to a hormone-primed female, but aspects of their interactions were aversive, the male might fail to display the social preference. Wild-type and ERoKO males were similar in spending significantly more time in chambers with any class of social partner than in the neutral compartment, but differed in the amount of chemo-investigation of intact females or those ovariectomized and treated with oestradiol. As expected, wild-type males spent significantly more time investigating females than males; likewise, they spent significantly more time sniffing the ovariectomized plus oestradiol-treated females than the ovariectomized females. In contrast, ERoKO males displayed very little chemo-investigatory behaviour toward any of the stimulus animals (Wersinger and Rissman, 2000b). The tentative conclusion reached was that ER $\alpha \mathrm{KO}$ males lack sexual motivation. To test this hypothesis, we investigated whether the lack of ER $\alpha$ might affect sexual behaviour via the neurotransmitter dopamine, which has a well-characterized role in masculine sexual motivation.

\section{Dopamine and male sexual behaviour}

Dopamine facilitates the motivational, appetitive and motor aspects of sexual behaviour in three necessary sites. Dopamine in the nigrostriatal tract enables the motor components of sexual behaviour (Hull et al., 1998). In the mesolimbic tract, dopamine enhances appetitive behaviour and reinforcement. Preoptic area dopamine facilitates genital reflexes, sexual motivation and stereotyped sexual behaviours such as mounting and thrusting (Hull et al., 1998). It is possible that the role of dopamine is to prime these systems such that the appropriate sexual stimuli will elicit the proper sexual response.

If oestrogen receptor $\alpha$ acts directly or indirectly on dopamine pathways, it was predicted that dopamine stimulation could restore sexual behaviour in ER $\alpha$ KO mice. One added feature of this experiment was the addition of females. ER $\alpha$ KO and wild-type males and females were gonadectomized and treated with testosterone. Before testing, they were injected with apomorphine (APO), a dopamine agonist (Wersinger and Rissman, 2000a). It was found that ER $\alpha K O$ mice of both sexes that had been injected with $\mathrm{APO}$, but not vehicle, before the copulation test displayed mounting and thrusting with the stimulus females. In addition, half of the ER $\alpha K O$ males ejaculated (Fig. 1). Pretreatment with APO also restored normal rates of chemoinvestigation and social preferences for females in the ER $\alpha K O$ males. Wild-type and ER $\alpha K O$ females that received testosterone with or without APO did not show any chemoinvestigatory preferences.

There are several interpretations of these data. First, these findings may indicate that the required neural circuits upstream of dopamine release are not organized in ER $\alpha \mathrm{KO}$ males, but that administration of dopamine can overcome the lack of oestrogen receptor $\alpha$. Alternatively, oestrogen receptor $\beta$ may be sufficient to organize these pathways during development. However, the fact that females display masculine sexual behaviour indicates that male mounting and thrusting behaviours are relatively non-dimorphic in C57BL/6J mice. However, chemo-investigatory preferences are dimorphic, as neither wild-type nor ER $\alpha$ KO females displayed a preference. Thus, if oestradiol has an organizing role on male-like behaviour, sexual preference may be a better measure to study than male sexual behaviour. An alternative to the idea that either oestrogen receptor is required during development is the hypothesis that oestrogen receptor $\alpha$ is required only to activate masculine sexual behaviour. Thus, oestrogen receptor $\alpha$ may be involved with dopamine release. It is possible that oestrogen receptor $\alpha$ is necessary to activate a dopaminergic pathway required for sexual behaviour, especially in sexually naive mice. 
Repeated stimulation of this pathway may make these neural circuits more responsive to external sexual stimuli and less dependent on circulating steroids. The fact that sexually experienced castrated rats treated with APO show partial sexual behaviour (Scaletta and Hull, 1990) is consistent with this hypothesis.

\section{Dopamine and sex discrimination}

In primates, a decrease in dopamine due to ageing or neurodegenerative diseases may result in a functional attention deficit (Leranth et al., 2000). One hypothesis to explain the impaired chemo-investigation and interactive behaviours of ER $\alpha \mathrm{KO}$ mice is that lack of dopamine results in general impairment in attention that interferes with the ability of the male to recognize a female. Another line of support for the hypothesis that ER $\alpha$ KO males are unable to distinguish females from males comes from resident/ intruder aggression studies in wild-type and ERoKO males (Scordalakes and Rissman, in press). Non-aggressive, olfactory bulbectomized males or ovariectomized plus oestradiol-treated females were used as intruders for these studies; the male intruders were castrated and treated daily with either testosterone or oestradiol. Wild-type males quickly attacked bulbectomized castrated males treated with testosterone, were slower to attack castrated males treated with oestradiol and did not attack females. In contrast, ER $\alpha$ KO males attacked all stimulus animals. This result could be attributed to the inability of ER $\alpha K O$ males to discriminate males from females and, thus, to display inappropriate behaviours. In a second experiment, males were forced to interact with soiled bedding from the cage of the intruder for $30 \mathrm{~min}$ before contact with the stimulus animal. Under these testing conditions, ER $\alpha K O$ mice still did not differ in their behaviour toward males and females, but they were less aggressive to either sex. These data add support to the hypothesis that there may be fundamental failure of the olfactory discrimination pathway in ERoKO males.

\section{Dopamine release and neuronal nitric oxide synthase (nNOS)}

In males, testosterone is required for the release of dopamine in the POA (Hull et al., 1998). Lorrain et al. (1999) showed that dopamine release in the POA increases before and during copulation in gonad-intact rats. Castrated mice release less dopamine before and during contact with a female than afterwards. Although dopamine release decreased in castrated mice, the neural content of dopamine was increased by castration, which implies that production is normal (Hull et al., 1997). Therefore, if dopamine production is normal, the decreased concentrations of extracellular dopamine in castrated mice are caused by inadequate dopamine release. Several lines of evidence indicate that oestrogen receptor $\alpha$ may effect dopamine release through the production of nitric oxide by nNOS.

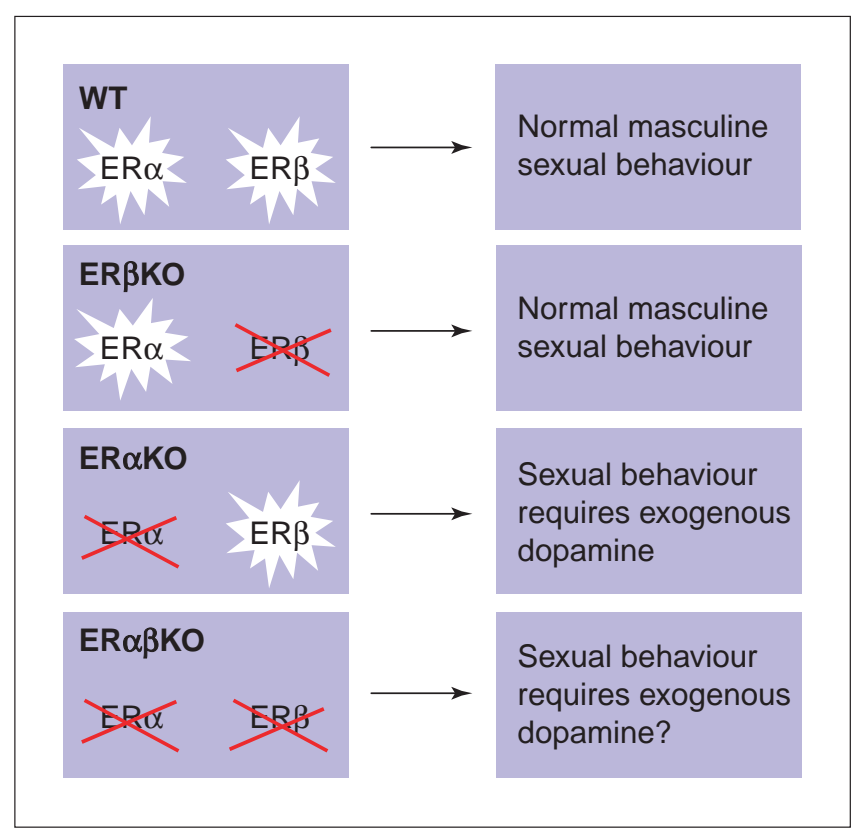

Fig. 2. Model showing hypothetical requirement for oestrogen receptor $\alpha(E R \alpha)$ and oestrogen receptor $\beta(E R \beta)$ in male sexual behaviour. Wild-type and ERßKO males show normal sexual behaviour. ER $\alpha K O$, and possibly $E R \alpha \beta K O$, males require a dopamine agonist to bypass the effects of oestrogen receptor $\alpha$ disruption.

nNOS is an important regulator of dopamine release in rats (Du and Hull, 1999). Hull et al. (1997) suggested that the lack of dopamine secretion was due to insufficient nitric oxide production. In support of this hypothesis, castrated rats have decreased numbers of nNOS immunoreactive cells (Du and Hull, 1999). Thus, because the number of nNOS immunoreactive cells was decreased, nitric acid production was significantly reduced and less dopamine was secreted. As decreased dopamine release was noted only in castrated mice, Du and Hull (1999) suggested that testosterone was responsible for regulating the presence of nNOS. However, NOS expression could also be regulated by oestradiol.

Studies using female rodents indicate that oestradiol treatment results in the upregulation of nNOS (Rachman et al., 1998; Isihara et al., 2001). Castration of male rodents results in a decrease in the number of nNOS immunoreactive cells (Hadeishi and Wood, 1996; Du and Hull, 1999). Recent evidence from our laboratory provides support for regulation of $\mathrm{nNOS}$ by oestrogen receptor $\alpha$. Immunohistochemical staining for nNOS in mice that have functional oestrogen receptor $\alpha$ but not androgen receptor ( $T f m$ males) shows that the area of NOS immunoreactivity staining is equivalent to that noted in the POA of wild-type males. In contrast, male mice lacking oestrogen receptor $\alpha$ $(E R \alpha K O)$ or oestrogen receptor $\alpha$ and androgen receptor $(E R \alpha K O / T f m)$ have a reduced area of nNOS immunoreactivity area staining in the POA (Scordalakes et al., in 


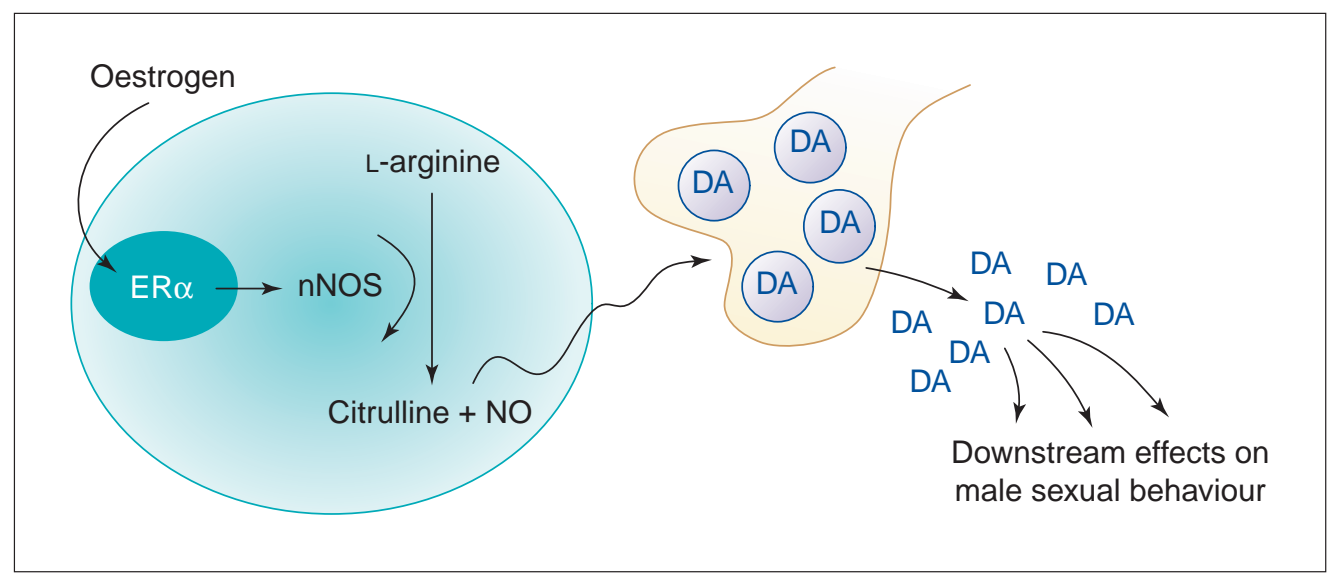

Fig. 3. Proposed model for activation of sexual behaviour of male mice. Oestrogen bound to oestrogen receptor $\alpha(E R \alpha)$ regulates neuronal nitric oxide synthase ( $\mathrm{nNOS}$ ) expression, production and transport. nNOS synthesizes nitric oxide by conversion of L-arginine to citrulline. Nitric oxide, a diffusible neurotransmitter, induces the release of dopamine (DA) from pre-synaptic terminals. Dopamine then facilitates the expression of male sexual behaviour, possibly via increased motivation and reward.

press). This finding indicates that oestrogen receptor $\alpha$ may be required to upregulate $\mathrm{nNOS}$ expression in a site-specific way, as this effect was noted only in one area. In addition, gonadectomized, testosterone-treated wild-type females show a reduced area of nNOS immunoreactivity staining compared with wild-type males and Tfm males, but have more staining compared with males lacking oestrogen receptor $\alpha$. This comparison indicates that oestrogen receptor $\alpha$ is also important at the time of neonatal development to organize the POA in a masculine way.

\section{Conclusions and future directions}

Our data, taken together with information from other laboratories, indicate that the effects of oestrogen during development are elicited primarily via actions on oestrogen receptor $\alpha$. However, if oestrogen receptor $\alpha$ is not functional, some organization of masculine sexual behaviour is still possible. This may occur via androgen receptor, oestrogen receptor $\beta$ or a non-steroidal mechanism (Arnold, 1996). Thus, we hypothesize that, normally, oestrogen receptor $\alpha$ and oestrogen receptor $\beta$ act in a complementary manner (Fig. 2). In adult ERßKO mice, sexual behaviour is not impaired, yet several sex differences in neural oestrogenic responses are reversed in ERßKO versus wild-type littermates (Temple et al., 2001). One study has described the inability of male ER $\alpha \beta K O$ mice to display masculine sexual behaviour (Ogawa et al., 2000). The speculation based on this result is that normal adult sexual behaviour requires both oestrogen receptors. However, the optimal test of this hypothesis is to treat double knockout males with dopamine. If masculine behaviour is still not displayed under these conditions then the developmental actions of oestrogens via oestrogen receptor $\alpha$ or $\beta$ are required for adult masculine behaviour. In contrast, if double ER $\alpha \beta K O$ can display sexual behaviour when given dopamine treatment then it is possible that androgen receptor, another oestrogen-responsive protein, or a non-steroidal factor can affect the organization of sexual behaviour neural circuits. The speculation of Arnold (1996) that genes on the $Y$ chromosome may influence neural differentiation would be supported by this outcome.

Our data also indicate that the adult action of oestrogen on masculine sexual behaviour is very restricted. We hypothesize that oestrogen regulates NOS in the POA, which, in turn, potentiates extracellular dopamine release (Fig. 3). This function is particularly critical for sexually naive animals that have not experienced sex and do not yet display a reflexive release of dopamine associated with encountering a female. Perhaps this is the reason why antioestrogen receptor blockers have little effect in studies in which males are prescreened for sexual competence and then tested for sexual behaviour after castration. As we have stated before, it is also noteworthy that dopamaine can reinstate sexual activity in sexually experienced, but not in sexually naive, castrated animals. Future studies conducted in our laboratory and our colleagues' laboratories will test these hypotheses further.

The authors would like to thank Paul Heideman for his careful editorial comments and assistance. The authors are also indebted to Dennis Lubahn for generously providing us with the heterozygotic ER $\alpha K O$ mice and to Jan-Åke Gustafsson for the ERßKO mice used to start our colonies. Our research on the role of steroids in masculine sexual behaviour is supported by $\mathrm{NIH}$ awards R01 MH57759 and K02 MH01349 to E. F. Rissman. D. B. Imwalle was supported by NIH training grant HD072323.

\section{References}

Key references are indicated by asterisks.

Arnold AP (1996) Genetically triggered sexual differentiation of brain and behavior Hormones and Behavior 30 495-505 
Bakker J, Baum MJ and Slob AK (1996) Neonatal inhibition of brain estrogen synthesis alters adult neural Fos responses to mating and pheromonal stimulation in the male rat Neuroscience 74 251-260

Baum MJ and Vreeburg JT (1973) Copulation in castrated male rats following combined treatment with estradiol and dihydrotestosterone Science 182 283-285

Beach FA, Noble RG and Orndoff RK (1969) Effects of perinatal androgen treatment on responses of male rats to gonadal hormones in adulthood Journal of Comparative Physiology and Psychology 68 490-497

Bean NJ, Nyby J, Kerchner M and Dahinden Z (1986) Hormonal regulation of chemosignal-stimulated precopulatory behaviours in male housemice (Mus musculus). Hormones and Behaviour 20 390-404

Clemens LG, Wee BEF, Weaver DR, Roy EJ, Goldman BD and Rakerd B (1988) Retention of masculine sexual behavior following castration in male B6D2F1 mice Physiology and Behavior 42 69-76

Craigen W and Bronson FH (1982) Deterioration of the capacity for sexual arousal in aged male mice Biology of Reproduction 26 869-874

*Crawley JN, Belknap JK, Collins A et al. (1997) Behavioral phenotypes of inbred mouse strains: implications and recommendations for molecular studies Psychopharmacology 132 107-124

Davis PG and Barfield RJ (1979) Activation of masculine sexual behavior by intracranial estradiol benzoate implants in male rats Neuroendocrinology 28 217-227

Du J and Hull EM (1999) Effects of testosterone on neuronal nitric oxide synthase and tyrosine hydroxylase Brain Research 836 90-98

Edwards DA and Burge KG (1971) Early androgen treatment and male and female sexual behavior in mice Hormones and Behavior 2 49-58

Gaspar M-L, Meo T, Bourgarel P, Guenet J-L and Tosi M (1991) A single base deletion in the Tfm androgen receptor gene creates a short-lived messenger RNA that directs internal translation initiation Proceedings National Academy of Sciences USA 88 8606-8610

Gondos B (1980) Development and differentiation of the testis and male reproductive tract. In Testicular Development, Structure and Function pp 3-20 Eds A Steinberger and B Steinberger. Raven Press, New York

Hadeishi Y and Wood RI (1996) Nitric oxide synthase in mating behavior circuitry of male Syrian hamster brain Journal of Neurobiology 30 480-492

Holman SD (1976) Neonatal androgen and mounting behaviour in female house mice Animal Behavior 24 135-140

Honda S, Harada N, Ito S, Takagi Y and Maeda S (1998) Disruption of sexual behavior in male aromatase-deficient mice lacking exons 1 and 2 of the cyp19 gene Biochemical and Biophysical Research Communications 252 445-449

Houtsmuller EJ, Brand T, de Jonge FH, Joosten RN, van de Poll NE and Slob AK (1994) SDN-POA volume, sexual behavior, and partner preference of male rats affected by perinatal treatment with ATD Physiology of Behavior 56 535-541

*Hull EM, Du J, Lorrain DS and Matuszewich L (1997) Testosterone, preoptic dopamine, and copulation in male rats Brain Research Bulletin 44 327-333

Hull EM, Lorrain DS, Jianfang D, Matuszewich L, Britan D, Nishita JK and Scaletta LL (1998) Organizational and activational effects of dopamine on male sexual behavior. In Males, Females and Behavior: Toward Biological Understanding pp 79-96 Eds L Ellis and L Ebertz. Praeger, London

Isihara T, Araki T and Sakuma Y (2001) Two distinct populations of neurons expressing nitric oxide synthase mRNA in the female preoptic area: site specific changes induced by sex steroids Journal of Nippon Medical School 68 328-334

Jost A (1970) Hormonal factors in the sex differentiation of the mammalian foetus Philosophical Transactions, Royal Society of London, Biological Sciences 259 119-130

Krege JH, Hodgin JB, Couse JF et al. (1998) Generation of reproductive phenotypes of mice lacking estrogen receptor $\beta$ Proceedings National Academy of Sciences USA 95 15 677-15682

Kuiper GGJM, Enmark E, Pelto-Huikko M, Nilsson S and Gustafsson JA (1996) Cloning of a novel estrogen receptor expressed in rat prostate and ovary Proceedings National Academy of Sciences USA 93 5925-5930

Lephart ED, Simpson ER, McPhaul MJ, Kilgore MW, Wilson JD and Ojeda
SR (1992) Brain aromatase cytochrome P-450 messanger RNA levels and enzyme activity during prenatal and perinatal development in the rat Molecular Brain Research 16 187-192

Leranth C, Roth RH, Elswoth JD, Naftolin F, Horvath TL and Redmond DE (2000) Estrogen is essential for maintaining nigrostriatal dopamine neurons in primates: implications for Parkinson's disease and memory Journal of Neuroscience 20 8604-8609

Lorrain DS, Matuszewich L, Howard RV, Du J and Hull EM (1999) Nitric oxide promotes dopamine release during male rat copulation Neuroreport 8 31-34

Lovell-Badge R (1993) Sex determining gene expression during embryogenesis Philosophical Transactions of the Royal Society of London 339 159-164

*Lubahn DB, Moyer JS, Golding TS, Couse JF, Korach KS and Smithies O (1993) Alteration of reproductive function but not prenatal sexual development after insertional disruption of the mouse estrogen receptor gene Proceedings National Academy of Sciences USA 9011 162-11 166

Luttge WG and Hall NR (1973) Differential effectiveness of testosterone and its metabolites in the induction of male sexual behavior in two strains of albino mice Hormones and Behavior 4 31-43

McCarthy MM, Schlenker EH and Pfaff DW (1993) Enduring consequences of neonatal treatment with antisense oligodeoxynucleotides to estrogen receptor messenger ribonucleic acid on sexual differentiation of rat brain Endocrinology 133 433-439

McGill TE (1962) Sexual behaviour in three inbred strains of mice Behaviour 19 341-350

*Meisel RL and Sachs BD (1994) The physiology of male sexual behavior. In The Physiology of Reproduction pp 3-106 Eds E Knobil and JD Neill. Raven Press, New York

Merkx J (1984) Effect of castration and subsequent substitution with testosterone, dihydrotestosterone and oestradiol on sexual preference behavior in male rats Behavioral Brain Research 11 59-65

Naftolin F (1994) Brain aromatization of androgens Journal of Reproductive Medicine 39 257-261

Nunez AA, Nyby J and Whitney G (1978) The effects of testosterone, estradiol, and dihydrotestosterone on male mouse (Mus musculus) ultrasonic vocalizations Hormones and Behavior 11 264-272

Nyby JG, Dizinno G and Whitney G (1977) Sexual dimorphism in ultrasonic vocalizations of mice (Mus musculus): gonadal hormone regulation Journal of Comparative Physiology 91 1424-1431

Ogawa S, Chan J, Chester AE, Gustafsson JA, Korach KS and Pfaff DW (1999) Survival of reproductive behaviors in estrogen receptor $\beta$ genedeficient ( $\beta$ ERKO) male and female mice Proceedings National Academy of Sciences USA 9612 887-12 892

Ogawa S, Chester AE, Hewitt SC, Walker VR, Gustafsson JA, Smithies O, Korach KS and Pfaff DW (2000) From the cover: abolition of male sexual behaviors in mice lacking estrogen receptors $\alpha$ and $\beta$ ( $\alpha \beta E R K O)$ Proceedings National Academy of Sciences USA 97 14 737-14 741

Olsen KL (1992) Genetic influences on sexual behavior differentiation. In Sexual Differentiation, Handbook of Behavioral Neurobiology pp 1-40 Eds AA Gerall et al. Plenum Press, New York

Phoenix CH, Goy RW, Gerall AA and Young WC (1959) Organizing action of prenatally administered testosterone propionate on the tissues mediating mating behavior in the female guinea pig Endocrinology 65 369-382

Prince KN, Prince JS, Kinghorn EW, Fleming DE and Rhees RW (1998) Effects of sexual behavioral manipulation on brain plasticity in adult rats Brain Research Bulletin 47 349-355

Rachman IM, Unnerstall JR, Pfaff DW and Cohen RS (1998) Regulation of neuronal nitric oxide synthase mRNA in lordosis-relevant neurons of the ventromedial hypothalamus following short-term estrogen treatment Molecular Brain Research 59 105-108

Reddy VV, Naftolin F and Ryan KJ (1974) Conversion of androstenedione to estrone by neural tissues from fetal and neonatal rats Endocrinology $\mathbf{9 4}$ $117-121$

Rissman EF, Early AH, Taylor JA, Korach KS and Lubahn DB (1997a) Estrogen receptors are essential for female sexual receptivity Endocrinology 138 507-510

Rissman EF, Wersinger SR, Taylor JA and Lubahn DB (1997b) Estrogen 
receptor function as revealed by knockout studies: neuroendocrine and behavioral aspects Hormones and Behavior 31 232-243

Rissman EF, Wersinger SR, Fugger HN and Foster TC (1999) Sex with knockout models: behavioral studies of estrogen receptor $\alpha$ Brain Research 835 80-90

Robertson KM, Simpson ER, Lacham-Kaplan O and Jones ME (2001) Characterization of the fertility of male aromatase knockout mice Journal of Andrology 22 825-830

Roselli CE, Salisbury RL and Resko JA (1987) Genetic evidence for androgen-dependent and independent control of aromatase activity in the rat brain Endocrinology $1212205-2210$

Roselli CE, Abdelgadir SE and Resko JA (1997) Regulation of aromatase gene expression in adult rat brain Brain Research Bulletin 44 351-357

Scaletta LL and Hull EM (1990) Systemic or intracranial apomorphine increases copulation in long-term castrated male rats Pharmacology, Biochemistry and Behavior 37 471-475

Scordalakes EM and Rissman EF (2002) Intruder aggression in male mice lacking functional estrogen receptor $\alpha$ Behavioral Neuroscience (in press)

Scordalakes EM, Shetty SJ and Rissman EF (2002) Roles of estrogen receptor $\alpha$ and androgen receptor in the regulation of neuronal nitric oxide synthase Journal of Comparative Neurology (in press)

Temple JL, Fugger HN, Li X, Shetty SJ, Gustafsson JA and Rissman EF (2001) Estrogen receptor $\beta$ regulates sexually dimorphic neural responses to estradiol Endocrinology 142 510-513

Vagell ME and McGinnis MY (1997) The role of aromatization in the resolution of male rat reproductive behavior Journal of Neuroendocrinology 9 415-421

Vagell ME and McGinnis MY (1998) The role of gonadal steroid receptor activation in the restoration of sociosexual behavior in adult male rats Hormones and Behavior 33 163-179

Vale JR, Ray D and Vale CA (1973) The interaction of genotype and exogenous neonatal androgen and estrogen: sex behavior in female mice Developmental Psychobiology 6 319-327

Vega Matuszczyk JV and Larsson K (1995) Sexual preference and feminine and masculine sexual behavior in male rats prenatally exposed to antiandrogen or anti-estrogen Hormones and Behavior 29 191-206

Veney SL, Rissman EF and Freeman LM (2000) Perinatal organization of a sexually dimorphic aromatase enzyme-containing immunoreactive nucleus Neuroreport 11 3409-3412

*Wersinger SR and Rissman EF (2000a) Dopamine activates masculine sexual behavior independent of the estrogen receptor alpha Journal of Neuroscience 20 4248-4254

Wersinger SR and Rissman EF (2000b) Oestrogen receptor $\alpha$ is essential for female-directed chemo-investigatory behaviour but is not required for the pheromone-induced luteinizing hormone surge in male mice Journal of Neuroendocrinology 12 103-110

Wersinger SR, Sannen K, Villable C, Lubahn DB, Rissman EF and DeVries GJ (1997) Masculine sexual behavior is disrupted in male and female mice lacking a functional estrogen receptor $\alpha$ gene Hormones and Behavior 32 176-183

Wilson JD (1989) Sexual differentiation of the gonads and of the reproductive tract Biology of the Neonate 55 322-330

Wood RI and Swann JM (2000) Neuronal integration of chemosensory and hormonal signals in the control of male sexual behavior. In Reproduction in Context pp 423-444 Eds K Wallen and JE Schneider. MIT Press, Cambridge, MA 